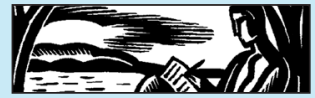

\title{
Understanding Literary Diatexts: Approaching the Archive of Richmal Crompton, the Creator of 'Just William' Stories
}

\author{
Dr. Jane McVeigh
}

University of Roehampton

\section{ABSTRACT}

Richmal Crompton was born in Bury, Lancashire on 15 November 1890 and she wrote and published 'Just William' stories from 1919. She was very prolific, and published thirty-eight 'Just William' story collections, some forty novels and other short story collections. She is most famous for her stories about an eleven year old boy called William who features in the 'Just William' stories. Crompton often wrote ideas on fragments of paper. Her archive at the University of Roehampton also includes letters and other documents from fans, friends, family, local organisations and businesses which have, on the other side, ideas for her stories. The archive houses Crompton's library taken by her family from her last home. Personal notes and postcards from friends were found inside these books. Moreover, the archive includes other personal items, such as her desk, typewriter and glasses. This essay will consider how we can understand the archive of the author, Richmal Crompton, based on a diatextual analysis that draws connections across the fluid boundaries that all of this material creates within this physical and imaginative space.

Keywords: feminine middlebrow, archives, intra-actions, Richmal Crompton 
Richmal Crompton wrote and published 'Just William' stories from 1919. These stories were published across Europe and were at their height of popularity in the early to mid-twentieth century. 'Just William' stories have been important in the lives of millions of children and adults since the 1920 s and have been read in many languages.

This illustrated essay considers one way that researchers might approach this physical and imaginative space. It will discuss my own research in the context of the objects, books and narrative fragments which are held within Crompton's archive at the University of Roehampton. An initial theoretical discussion will set the scene for an analysis of some of this material. It will consider recent criticism on archival research and introduce a diatextual approach to studying this particular literary archive.

The archive is based on objects, books, manuscripts, letters and other textual material that were taken from Crompton's last home following the death of her niece Richmal Ashbee. It has been held on behalf of Richmal Crompton's family at the University of Roehampton since 2008. Researchers have yet to discover the wealth of material in this archive and this is the first essay to discuss its potential.

Crompton often wrote ideas on fragments of paper. Her archive also includes letters and other documents from fans, friends, family, local organisations and businesses which have, on the other side, ideas for her stories. Personal notes and postcards from friends were found inside her books. Moreover, the archive includes other personal items, such as her desk, typewriter and glasses. These objects and texts all form part of the materiality and diatextuality, a concept explained in the first section of this essay, which help us to understand both Crompton's private reading, her life as a writer, and give an insight into other aspects of her life.

In Working in Women's Archives (2001), edited by Helen M. Buss and Marlene Kadar, a number of key points emerge which underpin my own research methodology. Namely, that archives are not neutral sites of primary research (Buss 2) and we need to consider the assumptions which have been made about the documents and objects which are considered valuable. We also need to consider our own perspective as researchers, which inform the value we place on different types of archival evidence (Buss 2). Also, an archive can offer many versions of subjectivity (2) and, as feminist researchers, we need to understand that archival material, on the basis that it is relational (Verduyn 95), encompasses the public and private aspects of a life. Finally, any archive is incomplete and fragmentary and becomes a complex site of dialogic material which offers a range of different influences and representations (Kadar 115). Also, 
archives may conceal as much as they reveal (Douglas 54) and we have to look for what is missing. Research on Crompton's archive certainly has raised a series of questions about the type of evidence held within it and what, as Douglas suggests, might be missing. In particular, the archive includes very few letters written by Crompton herself and there are no diaries or journals. For such a prolific writer this seems surprising, but it suggests a life that has been well-hidden from the gaze of the public and biographer alike. As a researcher it is important not to undervalue the evidence that is available in the archive and the wealth of information it provides about the many versions of Richmal Crompton we can find there, including the writer, loving daughter, sister, aunt, great-aunt, caring and devoted friend and dedicated correspondent with fans. The different selves that we uncover, and the wealth of dialogic material available, suggest that we must focus on the evidence we have and the stories that it can tell us.

In another study, Lisa Stead argues that archives shape and reframe the reclamation and representation of literary figures and that this reshaping of the borders of an archive occurs between the physical site of the archive and our experience of it as a conceptual, imaginative space (2). These borders or boundaries keep changing as new material is added and researchers find different ways of engaging with archival materials. Stead also suggests that our experience of archives is multisensory, including touch and smell, as well as our reading and visual experience. ${ }^{1}$ The borders and boundaries in Crompton's archive are certainly very fluid as boxes of letters, manuscripts, postcards, photographs and other textual details are 'discovered' by researchers and new material continues to be added to it.

The individual texts, objects and books in this archive can be understood as biographemes, which are described by Roland Barthes as comprising "a few details, a few preferences, a few inflections" (9). There is a distinctly dialogic element to their materiality and content. Barthes suggests that the "text is an object of pleasure [of the mind]" (7) that we connect with someone in particular and may touch on our own lives, when "a co-existence occurs" (7). I am interested in the co-existence between researcher and Crompton, the archive's subject, during my research. So, our work in archives becomes an act of remembrance, of memory, in which the details of someone else's life and our mediation or interpretation as researchers come to co-exist in a moment of reading. This mediation cannot be fixed and has no unity, but it offers a moment of pleasure that we, as researchers, then share with others.

In this context, I am drawn to Maria Tamboukou's approach to intraactions in archival research, which describes a fluid research process 
that happens inside and beyond our work in the actual archive. Tamboukou argues that "the researcher's questions, interpretations, theoretical insights and analytical tropes emerge as intra-actions between space/time/matter relations and forces within the archives" ("Archival Research" 617); in other words, intra-actions "occur as relations between components" (621), human and non-human. Tamboukou is interested in the entangled intra-actions "between 'the researcher,' 'the research object' and 'the research context'" (622). In the case of research on Crompton's archive, this process is based on the entanglements between: the 'research object', including Crompton's books, narrative fragments, desk, photographs and glasses; and, in the case of this archive, 'the researcher' mediating the experience of the archive as a complex, relational, dialogic and fragmentary site; and finally, the 'research context' which is both a physical and an imaginative space based on a university campus, but open to the public as well. In doing so, this research makes connections across Crompton's archive, and offers a form of feminist revisioning in which we can see aspects of the professional and private life of this author. We come to understand something of the relationship between her professional life as a writer and her life as a woman with a close family, loyal friends and interests in community organisations and charities. The relational nature of this revisioning does not give the researcher an understanding of what Crompton may have actually thought or felt, but it can suggest aspects of her life that were important to her and are transformed in her unpublished and published writing. In this context, this study explores many of the different types of connections made by a researcher as she journeys through this archive. In the case of a writer like Crompton, whose writing and life have been hidden from view for far too long, this archival research also offers an opportunity for the lost voice of a forgotten writer to be heard. ${ }^{2}$

Crompton's archive, including her library, can be understood both as a collection, and as something of interest for the individual books that she read, as well as for the other individual items held within it. In the case of her library, we have a collection which encompasses a broad range of interests, including specific collections on poetry, gardening, contemporary drama, Greek drama and philosophy, and contemporary novels, to name but a few. ${ }^{3}$ These books are an important part of the archival material that can inform research on Crompton's life and writing. In her biography of Edith Wharton, Hermione Lee writes about the importance of Wharton's library and books which "do not just provide evidence of her life-story, they were also protagonists in it, and the equivalent of old friends" (670). Lee notes that, "Wharton's novels 
and stories are full of book-lined studies and discriminating collectors. Private libraries are the place where friendships are made" (132). Similarly, I would argue that Crompton's library becomes both a physical and imaginative space which provides evidence of her reading and writing life. And books and libraries, usually within a personal study used by one of the main characters, are certainly featured in her novels. ${ }^{4}$ As Lee suggests, the books in Crompton's archive can be understood in the context of the relationship between the subjectivity of the library owner and the books as objects. Walter Benjamin writes metaphorically about the importance of his library and his experience as a book collector. He argues that

Ownership is the most intimate relationship that one can have to objects. Not that they come alive in him [a book collector]; it is he who lives in them.

So I have erected one of his dwellings, with books as the building stones, before you, and now he is going to disappear inside, as is only fitting. (262)

So, we can similarly find the collector - Richmal Crompton - inside her library, like a spectral figure, and my research suggests that the borders and boundaries of this collection keep changing as we make new discoveries about what it contains. ${ }^{5}$

An analysis of objects is also relevant to a study of some of the other things in Crompton's archive, such as her desk, typewriter and glasses. Bill Brown encourages us to distinguish between aspects of what we mean by a thing: the thing that an object becomes as, he argues, "we look through objects" (140) to find meaning, and the independent, functional use of the object itself. In other words, our understanding of a thing relates to our experience of that object - a kettle is an electrical object that sits on our kitchen worktop and heats up water, but it also becomes both a thing which helps us to make a cup of tea and a thing associated with coming home from work, relaxing for a brief moment, or having some time with friends or family. Brown theorises that the "story of objects asserting themselves as things ... is ... the story of how the thing really names less an object than a particular subject-object relation" (140), and things are imagined "as what is excessive in objects, as what exceeds their mere materialization as objects or their mere utilization as objects" (141). So, how does this relate to a researcher's experience of a thing like a writer's desk? This is an object that serves both a functional purpose and is understood as a thing that represents a more imaginative space connected with the creative life of his or her archival subject. It is a large object that can be used to put smaller objects on, like typewriters and paper-weights. It is also a thing that can be used both for study or writing and is believed to represent a physical location where much of an author's imaginative and 
creative life takes place. So, research on material culture is concerned in part with our understanding of objects as relational and connected with the people who used them. It suggests that artefacts, like those kept in an archive or a museum, have social lives (Mytum 111). Both Harold Mytum and Chris Gosden support this approach and are less interested in the functional role of objects.

Mytum concentrates on the meaning of artefacts in his archaeological research:

The museum world has seen a particular value in considering the biography of objects, as these acquire meanings and values over time.... [An object] can have a collective and interpretative history that will be linked ... to aspects of its previous history. (112)

Gosden similarly argues that the meaning suggested by objects is important, as well as the meaning people impose on them ("What Do Objects Want?" 196), and he is interested in "how objects shape people and their social relations" (197). He agrees that objects' genealogy is important, but he seems particularly interested in the effects they have because, he argues, "the sorts of sensory and emotional responses that objects elicit are the key to their social power" (198) ${ }^{6}$ A study of Crompton's desk, typewriter and glasses does not suggest objects that are merely functional, although they clearly have their own individual history. We can understand them as part of the intra-actions described by Tamboukou. They raise questions about Crompton's material and imaginative life as a writer when she was living in her home, but they also have an effect on those of us who are seeing them as objects within an archival collection. For this researcher they raise questions about her daily writing routine; questions that we can wonder about, but are unlikely to be able to answer.

Finally, all of this material, understood as a collection, also has a more diverse and dialogic identity. This archival research suggests a complex exchange between a multiple range of dialogic influences which have a physical identity as well as imaginative impact. Psychologist Guiseppe Mininni, informed by the work of Mikhail Bakhtin, discusses the notion of the diatext as a "semiotic instrument for content analysis aimed at catching the dynamic and negotial nature of any communicative event" (168), and he argues that our experience of the world is diatextually framed because we are bound to ever-changing but always dialogically interpreted contexts. I would suggest that the study of Crompton's archive supports the notion of literary diatextual analysis, which arises out of intra-actions during a range of different reading event/s of two or more archival details. In this complex process, through the mediation 
of another's writing, such as a researcher or biographer, as well as, in some cases, a translator, the research can provide evidence of diatextual exchanges between different languages and cultures and specific and multiple connections between different types of narrative and physical objects. These unusual and unique connections are made by a researcher during moments or events of reading when, firstly, a moment of co-existence occurs, and secondly, two or more types of evidence or narrative are connected in both a physical and imaginative way. ${ }^{7}$ In other words, the connection has a material, as well as a conceptual or imaginative form, and the diatextual frame or dialogic nature of the reading event is based on communication between a number of different voices, objects and texts within this archival space. This is a concept which arises out of archival research, but could also apply to studies undertaken when the physical location of the evidence in question is located within another specific space, or building.

The second part of this paper now moves on to discuss specific evidence from Crompton's archive which provides examples of such literary diatextual analysis. The archive includes her private collection of books, including books in other European languages, particularly French, as well as copies of the translations of her 'Just William' books into other languages. Also on display are her novels, many dedicated to her mother. A number of her books when they arrived in the archive included notes and postcards from friends and personal items from her brother and sister, and this research has drawn on some of this material. Secondly, the archive includes a fascinating collection of fragments of paper, notes and ideas written on the back of correspondence and other documents and a range of personal and professional correspondence. For example, she received fan letters from across Europe and other parts of the world, including one which is in both the original Spanish and an English version provided by the publisher. In this case, research could encompass a diatextual analysis by a bilingual researcher who could consider the extent to which the translation, provided by the publisher, might have influenced Crompton's reading of this letter. This is a complex case of a specific intra-action in which an additional voice is heard. Finally, as well as her library, the archive includes a small number of objects, such as Crompton's desk, typewriter and glasses which form another part of the whole collection and can inform our understanding of her life as a writer of both private and professional texts. Crompton's archive draws on material located in her last home and shows how things from a previously private space, becomes public. The domestic environment is literally reformed as a professional space open to the scrutiny of others. 


\section{DIATEXTUAL ANALYSIS IN INTRA-ACTION}

A number of Crompton's books when they arrived in the archive included notes and postcards from friends. This is an example which tells us about a friend's holiday:

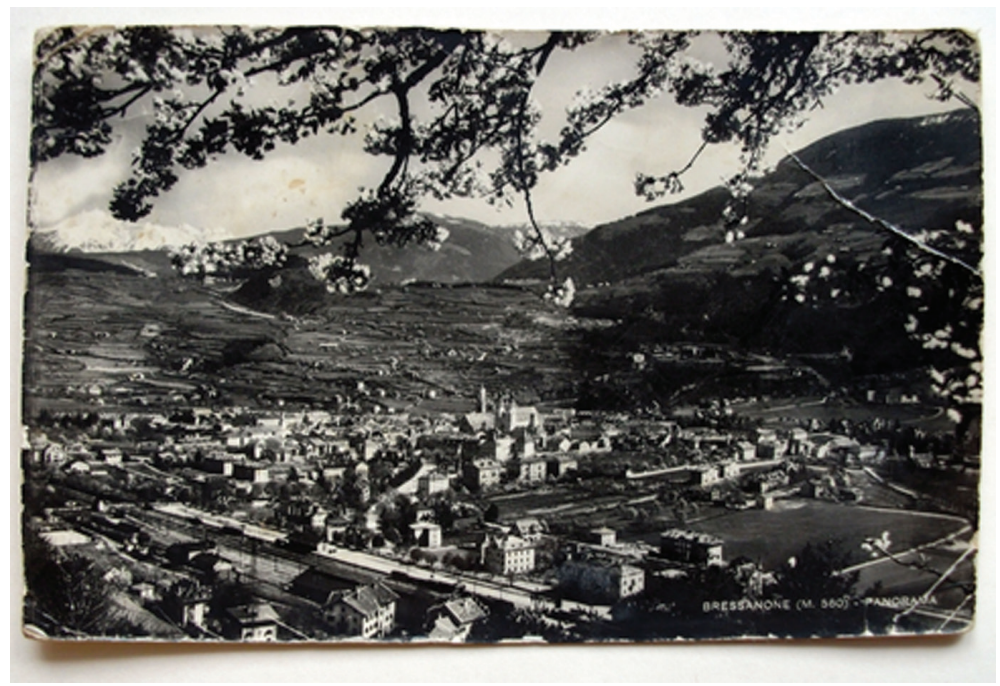

(Archives and Special Collections, University of Roehampton)

This is text that has its own look and feel; both the paper, the ink used on the other side and the photograph are faded, so we know, even without reading the text itself, that this is a moment from the past. ${ }^{8}$ What more could we learn about Crompton if we knew something about her relationship with this particular person? Should we assume that she kept this card because this person was special to her? In this act of reading a moment of the type of coexistence and intra-action described by Barthes and Tamboukou occurs. We know that Crompton kept personal correspondence; although whether she was just someone who reused paper for all sorts of purposes, as a bookmark in this case, or just kept particular correspondence or documents because they were important to her, is difficult to know. As Buss suggests, a researcher must be careful not to make too many assumptions about what was valuable to Crompton. However, this material has been assessed as valuable by someone, if not Crompton, certainly this researcher, and this in itself helps to explain how the boundaries of this 
archive keep changing as research makes new discoveries and tries to find out more about them so that we can assess their importance.

Other fragments of paper also used as bookmarks in other books in the library suggest family connections across decades of Crompton's life. For example, this is a fragment which makes a connection with Crompton's mother, Clara Lamburn, and was found in a book published in the 1950s. ${ }^{9}$ Her initials, CL, are visible under the inscription:

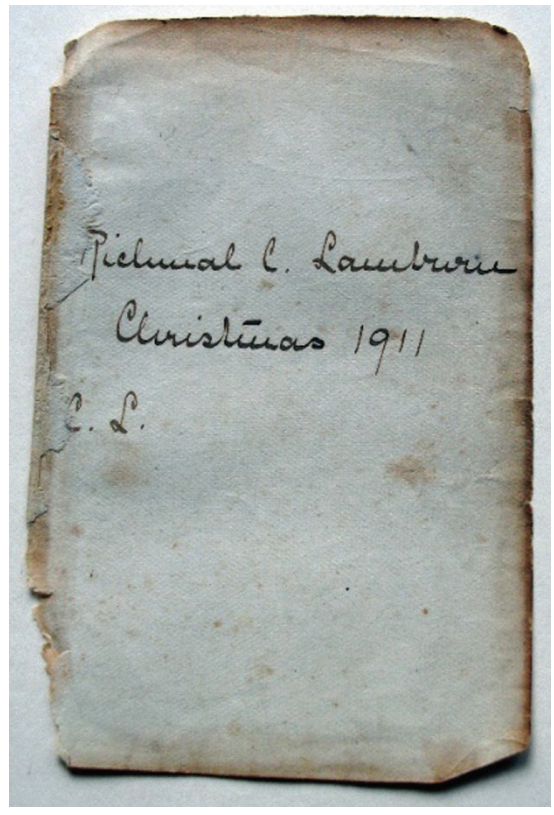

(Archives and Special Collections, University of Roehampton)

As mentioned in the abstract, Crompton was born in November 1890, so is this page from a special book given to her to mark her twenty-first year? We might be able to find out, but, at the very least, the fact that this fragment has been kept suggests that this page may have a special significance. This fragment connects with the library and the archive as a whole, which contains, for example, postcards sent by her mother when Richmal was away at school, family photographs, and a collection of Crompton's novels for adults, many of which are inscribed as follows: 'Mother. With all the author's love.'

In another book from the same period was found part of a card from John: 


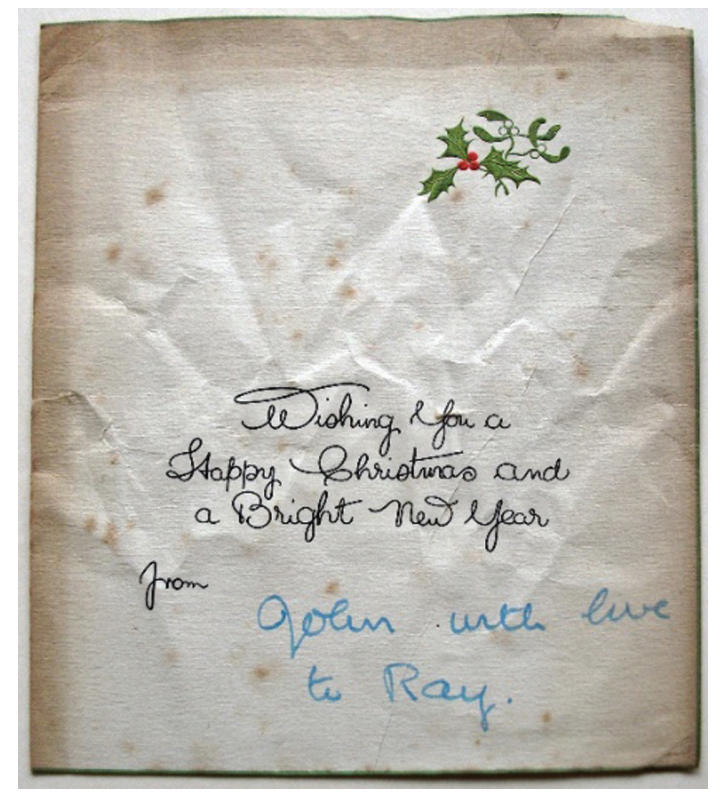

(Archives and Special Collections, University of Roehampton)

The front cover has been torn off, but Crompton's brother was called John and this evidence suggests, although this is speculation, that this is a card exchanged between brother and sister that Crompton kept all her life. ${ }^{10}$ In moments of reading her books, and in the physical and imaginative space of the archive, a researcher can feel the sort of effect described by Gosden - the connections between the value of Crompton's library, her individual books and these fragments of texts which resonate so strongly with her family life. Susan Stewart might describe them as "souvenirs of individual experience” (138); they are mementos from Crompton's past and within the archive there is a collection of similar material that evoke her childhood and many friendships.

Moving on, her archive also includes a fascinating collection of fragments of paper and notes and ideas written on the back of correspondence and other documents. They come together as a jumble of thoughts, written in different pens, on different types of paper and clearly written at different times in her life. Dealing with them is certainly a multi-sensory experience as they have their own smell, look and feel and offer personal details from a prolific writing and reading life.

This is an example of one fragment: 


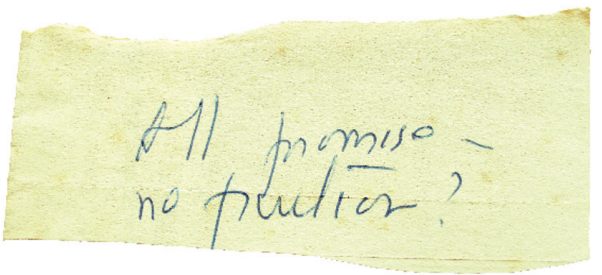

This reads: "All promise - no fruition"

(Archives and Special Collections, University of Roehampton)

We want to know why this thought; where does this fragment come from; what drove her to tear off this strip rather than write on a whole piece of paper? But, in the end, the answers to these questions do not really matter, since the detail that we have offers in itself a unique moment in my research. This is a fragment that has literary and archival value of itself.

This example comes across as a potential theme for her professional writing and could, if further research is undertaken, be understood as an example of the type of intertext, defined by Julia Kristeva ${ }^{11}$ :

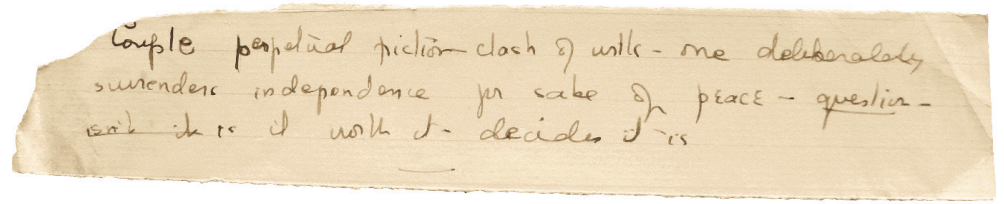

This fragment reads as follows: "Couple perpetual friction clash of wills - one deliberately surrenders independence for sake of peace question - is it worth it - decides it is"

(Archives and Special Collections, University of Roehampton)

Again, why this piece of paper? Where did she keep it? Did she go looking for it when she was writing? In the context of Barthes, in reading this text some kind of co-existence occurs. One can also think about the piece of paper as an object, a thing which is a detail from this writer's life. It is interesting to think about any connections between the home where this fragment came from and the archive where it is now. We can think about how the fragment is now stored in a folder within a white box and how this compares with where she might have kept it at home. It would be fascinating to know whether this fragment was held within the pages of a book in 
her library. There is also our experience of the intellectual space that this fragment opens up - as a researcher, a mediator, what do I understand it to represent?

The archive includes examples of texts where Crompton wrote on the back of different kinds of documents and suggests that she wrote ideas on all sorts of scraps of paper. Where did she keep them? She was not badly off financially, so what does this approach tell us about her writing life and the way that her ideas evolved? This is a letter from her agents about a deal with a Portuguese publisher to purchase two of her 'Just William' stories:

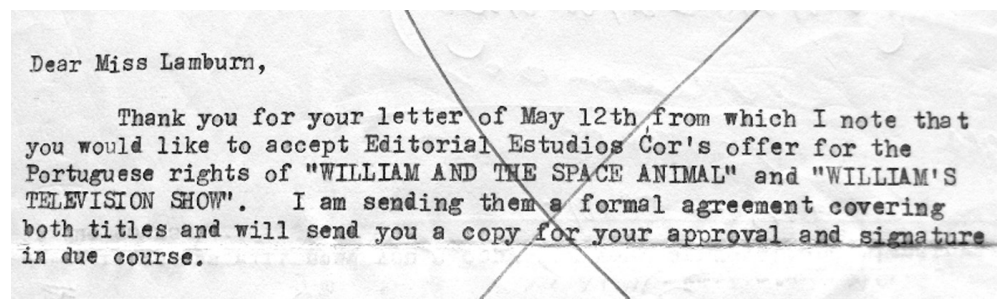

This letter reads: "Thank you for your letter of May $12^{\text {th }}$ from which I note that you would like to accept Editorial Estudios Cor's offer for the Portuguese rights of "William and the Space Animal" and "William's Television Show." I am sending them a formal agreement covering both titles and will send you a copy for your approval and signature in due course." (Archives and Special Collections, University of Roehampton)

On the back of this letter is a comment in the top left-hand corner, 'Get cat' and it includes on the bottom left-hand corner a shopping list: "crisps, cheese biscuits, gin, sherry, beef, sprouts, potatoes, wine, pineapple, cream, and cucumber." It sounds as though she might have been planning a dinner or lunch for family or friends. Apart from anything else, these fragment, and others like it (such as other letters from her publishers), suggests diatextual connections between different aspects of her professional life as a writer, a woman leading her day to day life, and a writer.

Crompton lived in Bromley, a quiet suburb of London, for much of her adult life and she was very supportive of local and national charities. This is an example of a document which relates to a local community organisation that Crompton supported. It is a letter from a youth organisation, the local Girl Guides Association, about the payment of her annual membership fee: 


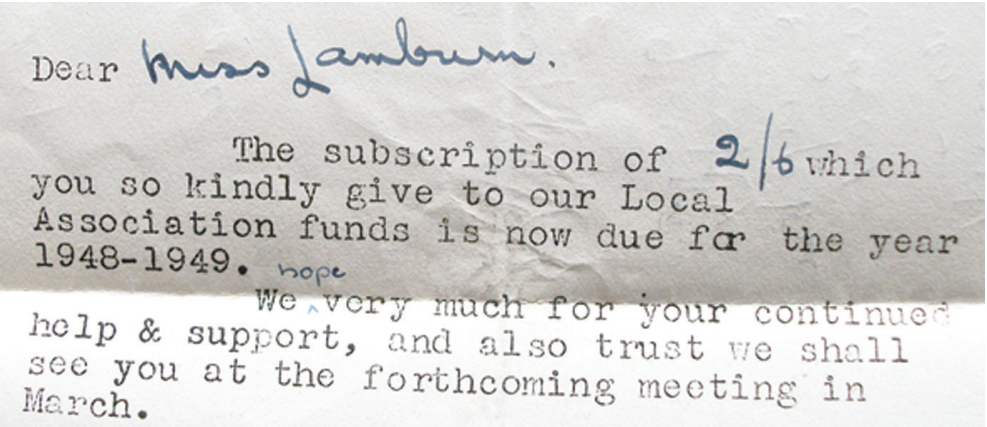

(Archives and Special Collections, University of Roehampton)

This is what is written on the back of this letter:

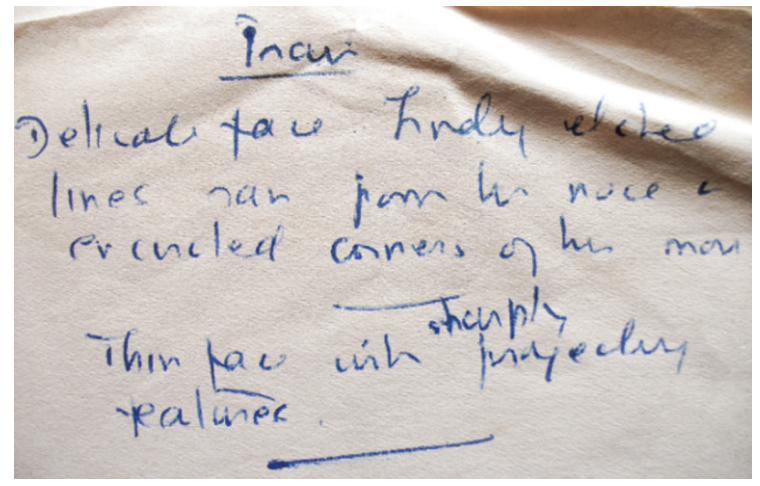

This reads: "Delicate face finely etched lines ran from her nose and encircled (?) corners of her mouth - Thin face with sharply projecting features" (Archives and Special Collections, University of Roehampton)

Further research might be able to unravel if these brief notes have a specific connection with her published writing and the extent to which it can be understood as an avante-text. We know that it would have informed her writing after the date of the letter, February 1949. However, the focus here is on the diatextual analysis that this archive offers; an opportunity to study all of these events of archival reading as a representation of a life in which borders between professional, private and day to day living merge and interact. 
There is another very interesting document which Crompton also used to note down her ideas. It is one page from the minutes of a meeting of a charity supporting disabled people that inappropriately has the term 'cripple' in the name of the organisation, and she has noted down ideas for her stories on the other side. Crompton was a disabled person herself and involved in charities like this one. But why does she keep this particular piece of paper? Of course, we do not know, this may just be one example of other similar fragments that never found their way to the archive, and there is no specific reason to think that it is significant. However, it does form part of a diatextual analysis within this archive which can be connected with, among others, evidence of Crompton's donations to other charities supporting disabled people, and letters from one particular fan over many years in which he comments on the support she has given him:

I was so sorry to learn that you suffer from lameness, but I sincerely hope
that it does not handicap your movements - that you can go for walks and
things. I am very grateful for your kind sympathy. I am getting better, thank
God, the pain is much less and I can sleep "naturally" about three hours
every night. Many, many kids are worse off than I am - refugees for example
... I have faith in the future - I believe that I will get better... God bless you,
Richmal Crompton, and thanks for your lovely letter, for all your kindness,
and for William ... ${ }^{12}$

At the very least, this evidence suggests Crompton's concern with the lives of disabled people and those suffering chronic ill health, something which she explores in a number of her novels. ${ }^{13}$ This section of the minutes is evidence of an important moment in the development of this organisation's support for disabled people. It describes a move to change the name of the charity to something which is representative of a less paternalistic approach and that is based on the right of disabled people to be treated as equals, rather than as mere recipients of charity. One speaker, not Crompton herself, comments:

"I think this old name is not 1918 but almost Dickensian. I think we should accept a new attitude of mind ... and as a disabled person I would beg you to vote for this with an overwhelming majority."

After Captain $[\mathrm{XX}]$... had said that all seventy ... [residents] of his Association's home disliked being described as "cripples," Dr. [XX] ... said: "As one of those who help with the treatment and care of most severely disabled people ... I can only endorse most warmly what the gentleman from Yorkshire has said. Today there are a great number of so called cripples who are 
self-respecting citizens ... They are full-time employees and taxpayers, and for them the word 'cripple' is absolutely abhorrent." 14

The minutes go on to note that the resolution to change the name of the society was "carried unanimously". A diatextual analysis of this evidence from the archive suggests the extent to which these texts place the unpublished writing of Crompton, the author, within a wider historical and social context. This is just one moment which reflects important mid-twentieth century changes in attitudes towards disabled people.

Finally, Crompton's desk and accompanying chair are important artefacts in her archive. These are very solid, rather formal items of furniture which do not suggest a relaxed reading and writing experience. Although, her desk has a kneehole space and she may have found it very comfortable. So, we have to be careful not to impose our own expectations on objects of this kind.

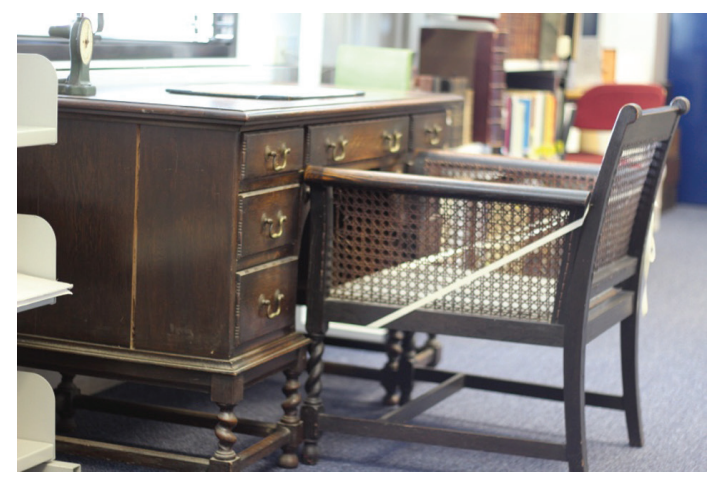

(Archives and Special Collections, University of Roehampton)

However, it is difficult to imagine that Richmal could have found this arrangement very practical as she coped with restrictions to her mobility following poliomyelitis in 1923. Is this an item in the archive that is representative of her life as a writer, but had little practical use to the writer herself? It would be interesting to know more about its history and the story that it could tell about her life. The desk itself has no inherent meaning, apart from its functional use, but the subject-object relationship could tell us a lot more about Crompton herself. The desk is an influential part of the archive because it offers some kind of access into Crompton's home. Where did she keep it? Her books are held within metal shelves and, like her desk, these are clearly non-institutional objects which would have previously been held in a very different space. 
This is also true of her typewriter:

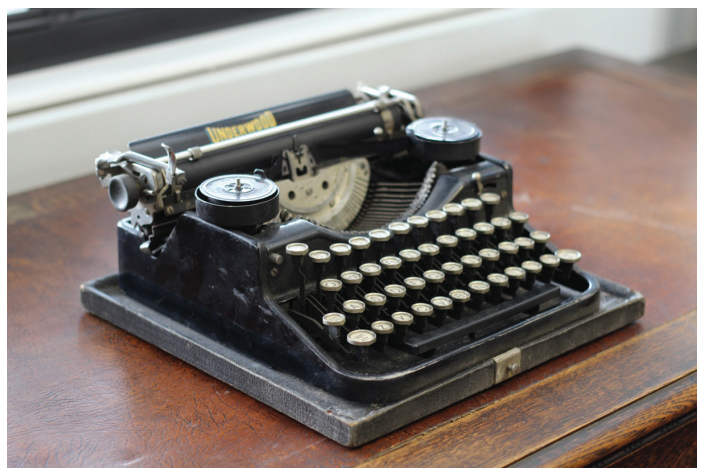

(Archives and Special Collections, University of Roehampton)

A diatextual analysis encourages all sorts of connections in the case of this object. It connects with her manuscripts, her private, public and professional correspondence and the time period in which she might have used it. It seems unlikely that she would have used this particular typewriter all of her writing life which went on until the late 1960s. The typewriter is an Underwood Standard Portable from the late 1920s. It seems in good condition, but an initial web search suggests that it is not an item which has any significant value as an antique. The date of the latest patent on the back is January 1927 and this period was a very prolific time for her writing. In 1927 she published two books of stories about the eleven year old William, William the Outlaw and William in Trouble, a further book followed in 1928, William the Good, and then three more in 1929, William's Christmas Truce, William Writes a Play and William. In this same three-year period she also published six books of short stories and six novels; six of these twelve books were published in $1928 .{ }^{15}$ The critical range of this writing is enormous, including middlebrow novels and short stories about the lives of women, ghost stories, in Mist and Other Stories (1928), and a novel about a new housing estate to which people from all walks of life have moved, Roof Off! (1928). This novel charts the major social changes of the period as the local estate, owned by the lady of the manor, is sold off to raise money and the owner of a local shop, the distressed middle class and the aspiring working classes all move in to the same small enclave of modernity. This typewriter may not have material value, but as something which connects us with this writing life it has real impact. ${ }^{16}$

Finally, a pair of her glasses is also held within the archive: 


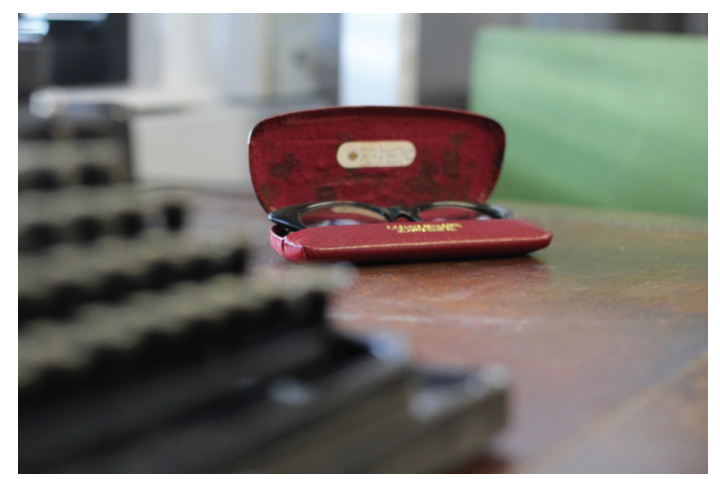

(Archives and Special Collections, University of Roehampton)

They have a label inside the red case marked 'Lamburn, Orpington Road, Chislehurst,' so we know that they came from her last home, Beechworth, where she moved in 1954. Ongoing research will hopefully find out more about their history, but an amateur's assessment of the lens would suggest that they are reading glasses and were therefore part of her reading and writing life. But, all we can know for certain is that they are held within her archive, albeit we would love to see the past through their lenses, as well as our own. Perhaps of particular note is the use of her given surname, Lamburn. In this essay, and in common currency about the author of William stories, is the writer's name, Richmal Crompton, but the woman herself was Richmal Lamburn. This is an important reminder to researchers and fans alike that much of what we know, or think we know, may not give us any authentic access to the life of Richmal Lamburn.

Who is the author? One might argue that the approach in this essay is privileging Richmal Crompton and undermining the voice of the other found in some of the narrative fragments discussed here. Although, one could also take the view, in the context of Tamboukou's intra-actions, that it is the researcher and her analysis that is taking centre stage. In this archive the role of the researcher involves understanding counter discourses in each event or moment of reading and as such offers a complex mediation experience. Research in a literary archive can identify unique and multi-layered connections between some of the texts and objects which are left to us. The archive tell us a great deal about both her writing and reading life and the extent to which a range of archival material were considered valuable enough for someone to keep them over many years, such as: personal souvenirs, including postcards and cards, evoking a nostalgic effect; fragments and notes which connect with her 
life as a writer and with other aspects of her professional and personal life; her library, which is representative of Crompton's writing and reading life, but also, connects with souvenirs of childhood and friendships; and objects from her home, which are representative of her writing life and reinforce an understanding of the archive as somewhere in which domestic objects can be re-imagined. This paper emphasises the dialogic and diatextual nature of archival research which encompasses all of this material in a physical and imaginative research space. This research is also interested in the archival moment of reading and each moment of co-existence when the researcher experiences something new. In the context of Benjamin's approach, this research can create its own collection.

One can almost imagine writing a book based on all of this reading and writing, including shopping lists. One could start each chapter not with a quotation from another writer, but with an image of one of these unusual and unique narrative fragments or objects from her archive that provide evidence of potential connections between different aspects of her life. It could then go on to tell a story based on each one and this story would be informed by the researcher's experience as a mediator and by moments of coexistence. This book would become a version of a virtual collection based on a diatextual reading of these unique details.

\section{WORKS CITED}

Bailey, Iain. "Allusion and Exogenesis: The Labouring Heart of Samuel Beckett's 'Ill Seen Ill Said'." Eds. Carrie Smith and Lisa Stead. The Boundaries of the Literary Archive: Reclamation and Representation. Farnham: Ashgate, 2013. 31-44. Print.

Barthes, Roland. Sade, Fourier, Loyola. Berkeley: University of California Press, 1976. Print.

Benjamin, Walter. "Unpacking my Library: A Talk about Book Collecting." Eds. Fiona Candlin and Raiford Guins. The Object Reader. Abingdon: Routledge, 2009. 257-262. Print.

Brown, Bill. "Thing Theory." Eds. Fiona Candlin and Raiford Guins. The Object Reader. Abingdon: Routledge, 2009. 124-138. Print.

Buss, Helen M. "Introduction.” Eds. Helen M. Buss and Marlene Kadar. Working in Women's Archives: Researching Women's Private Literature and Archival Documents. Waterloo: Wilfred Laurier Univerity Press, 2001. 1-6. Print.

Crompton, Richmal. Chedsy Place. London: Macmillan, 1934. Print.

Crompton, Richmal. Millicent Dorrington. London: Hodder and Stoughton, 1927.

Douglas, Jennifer. "Original Order, Added Value? Archival Theory and the Douglas Coupland Fonds." Eds. Carrie Smith and Lisa Stead. The Boundaries of the Literary Archive: Reclamation and Representation. Farnham: Ashgate, 2013. 45-60. Print.

Edwards, Elizabeth. "Photographs as Objects of Memory." Eds. Fiona Candlin and Raiford Guins. The Object Reader. London: Routledge, 2009. 331-342. Print.

Gosden, Chris, and Yvonne Marshall. "Cultural Biography of Objects." World Archaeology 31.2 (1999): 169-178. Online.

Gosden, Chris. "What Do Objects Want?" Journal of Archaeological Method and Theory 12.3 (2005): 193-211. Online. 
Kadar, Marlene. "Afterword." Eds. Helen M. Buss and Marlene Kadar. Working in Women's Archives: Researching Women's Private Literature and Archival Documents. Waterloo: Wilfred Laurier University Press, 2001. 115-118. Print.

Kadar, Marlene. "An Epistolary Constellation: Trotsky, Kahlo, Birney.” Eds. Helen M. Buss and Marlene Kadar. Working in Women's Archives: Researching Women's Private Literature and Archival Documents. Waterloo, Ontario: Wilfred Laurier University Press, 2001. 103-114. Print.

Lee, Hermione. Edith Wharton. London: Vintage, 2007. Print.

Mininni, Guiseppe. "Diatexts as a Mirror of Human Complexity." World Futures 61 (2005): 165-173.

Mytum, Harold. "Artefact Biography as an Approach to Material Culture: Irish Gravestones as a Material Form of Genealogy." The Journal of Irish Archaeology 12/13 (2003/2004): 111127. Online.

Stead, Lisa. "Introduction." Eds. Carrie Smith and Lisa Stead. The Boundaries of the Literary Archive: Reclamation and Representation. Farnham: Ashgate, 2013. 1-14. Print.

Stewart, Susan. On Longing: Narratives of the Miniature, the Gigantic, the Souvenir, the Collection. Durham: Duke University Press, 1993. Print.

Tamboukou, Maria. "Archival Research: Unravelling Space/Time/Matter Entanglements and Fragments." Qualitative Research 14.5 (2014): 617-633. Online.

Tamboukou, Maria. "'Portraits of Moments': Visual and Textual Entanglements in Narrative Research." Current Narratives 3 (2011): 3-13. Online.

Van Mierlo, Wim. "The Archaeology of the Manuscript: Towards Moden Palaeography." Eds. Carrie Smith and Lisa Stead. The Boundaries of the Literary Archive: Reclamation and Representation. Farnham: Ashgate, 2013. 15-30. Print.

Verduyn, Christl. "Personal Papers: Putting Lives on the Line - Working with the Marian Engel Archive." Eds. Helen M. Buss and Marlene Kadar. Working in Women's Archives: Researching Women's Private Literature and Archival Documents. Waterloo: Wilfred Laurier University Press, 2001. 91-102. Print.

\section{ABOUT THE AUTHOR}

Jane McVeigh was awarded her doctorate in 2013. She is working on her first book, Contemporary British Literary Biography: Haunting Conversations. Her research currently focuses on contemporary life-writing and Richmal Crompton's writing and archive, based at the University of Roehampton.

\section{NOTES}

1 Stead, Lisa "Introduction" in The Boundaries of the Literary Archive (2013), 1-14.

2 Although, the research discussed in this essay does not focus on her manuscripts, this type of study could also be an important subject for future research on Crompton. Wim Van Mierlo discusses the avante-text, such as manuscripts, in particular William Wordsworth's notebooks and the extent to which they informed his writing of The Prelude (1799). He suggests that we can find the pre-history of the poem in these notebooks (18). I am interested in this approach and there are certainly manuscripts of Crompton's stories and books in her archive which warrant further research in the context of genetic criticism and, in particular, exogenesis, which Ian Bailey describes as, "a genetic 
approach to intertextuality [that involves] establishing a writer's practices in selecting and appropriating pre-existing material, and then the ways in which [this] material has been reworked" (34). The archival material available at Roehampton could contribute significantly to this type of research on Crompton.

3 Crompton studied Greek as an undergraduate student at Royal Holloway.

4 Not surprisingly, in Crompton's novels a number of male characters have a study where they retreat to read, write personal or business correspondence, or sleep. But, Crompton's novels are interested in the lives of women who try to break down traditional boundaries and the study becomes one site where, in the spirit of Virginia Woolf, these boundaries are crossed by some of her women characters. For example, in Millicent Dorrington (1927), when Millicent takes on the role of both mother and father for her siblings, she carries on the tradition of her father who thought that "books ... have been more real to me than my children" (44) and in Millicent's life after his death the study, "was still the stronghold, the inviolate citadel of the house" (351).

5 Another aspect of this collection includes photograph albums, although they are not discussed in this essay. In common with Stead, Elizabeth Edwards argues that in considering the photograph in this way we "have to consider not just sight but touch and even smell" (335), because the "photograph has always existed, not merely as an image but in relation to the human body" (335). So, the sensory nature of these objects is important, as are the books held in Crompton's archive, and albums also have their own smell and "look like family bibles or medieval devotional books" (335). The viewer of a photograph album, in this case an archival researcher, influences the temporal reading of the album and fills in the gaps when photographs are missing (337). There are a number of photographs of people in the Crompton archive who are difficult to identify and some photographs from the albums are indeed missing. Another avenue for future research opens up.

6 In an earlier article Chris Gosden and Yvonne Marshall distinguish between "objects which can accumulate biographies to themselves [their own histories] and objects which contribute to the biography of a ceremony or body of knowledge, rather than accumulating their own inherent meanings" ("Cultural Biography of Objects" 176). In the case of this archive, Crompton's desk, typewriter and glasses contribute to a researcher's knowledge about the overall collection in the archive as a whole, as well as informing research on individual objects related to her life as a writer.

7 Maria Tamboukou describes this experience of reading as 'portraits of moments': "what it means to narrate the moment/the event, to tell stories whose end you do not know but which you actively want to re-imagine" ("Portraits of Moments" 5).

8 In the interests of confidentiality, I have not revealed the identity of the person who sent this card.

9 Richmal Lamburn is Richmal Crompton's family name, whilst Crompton, from her mother's side, is her professional name as a writer.

10 Richmal Crompton's brother was known as Jack later in life, so I am making an assumption here that this is a card from an early point in both their lives when he was known by his childhood name, John.

11 In her work on women's archives, Marlene Kadar is interested in Julia Kristeva's notion of the intertext which is linked to other texts,

because it makes either obvious or covert allusions to other texts; or, it simply refers to the same gallery of literary and linguistic conventions and devices as all other texts; or, utterances within texts intersect and thereby neutralize each other. ("An Epistolary Constellation" 108). 
This is an important notion, for example, in the study of letters and other first-person material which can be connected by a researcher with a writer's unpublished or professional writing because they share some elements of form, style, historical context, or content.

12 Archives and Special Collections, University of Roehampton.

13 For example, in Millicent Dorrington (1927), Millicent's sister, Lorna, loses her leg in an accident and her fiancé rejects her, but she goes on to have a very happy marriage and children. In Chedsy Place (1934) Mr Fielden comes to stay at the house with his wife, and other paying guests, for the Christmas weekend. He is blind and he becomes frustrated with his wife's over bearing care. She was a nurse and cared for him when he was injured and for him their relationship is based on need, not love: "He knew that she didn't mean to irritate him as much as she did, and he sometimes tried, though without much success, to control his irritation. After all, he had been glad enough to turn to her when Betty [his previous girlfriend] threw him over...." (128).

14 Archives and Special Collections, University of Roehampton.

15 The novels were: Millicent Dorrington (1927), Leadon Hill (1927), The Thorn Bush (1928), Roofs Off! (1928), The Four Graces (1929), Abbot's End (1929). The books of short stories were: A Monstrous Regiment (1927), The Middle Things (1928), Felicity Stands By (1928), Sugar and Spice and Other Stories (1928), Mist and Other Stories (1928), Ladies First (1929).

16 However, what we do not currently know is whether all of this work was written in this period, whether by hand or on a typewriter. Some of this published writing may represent the culmination of many years work and may only have been published as Crompton was becoming a successful author. 